\title{
Effect of Zeolite supplementation on rumen environment and forage digestion in bovine fed temperate pasture
}

\author{
J Vicentin 1, D Rearte 2, F Santini 2, J Elizalde 2 \\ 1UNER, CC 24, Oro Verde, 3100 Paraná, Entre Rios ; IINTA, EEA Balcarce, CC 276, \\ 7620 Balcarce, Buenos Aires, Argentina
}

High losses of $\mathrm{N}$ between mouth and duodenum were measured in ruminant grazing temperate pasture (Beever, 1986, Br J Nutr, 56 , 209 ). Protein of high quality forage is degradable in the rumen and $\mathrm{N}-\mathrm{NH}_{3}$ produced and not utilized by rumen bacteria is absorbed, converted to urea in the liver and excreted in urine. Zeolite $(Z)$ has the capability to trap $\mathrm{N}-\mathrm{NH}_{3}$ ions in excess and to liberate it later when concentration decrease.

The present trial was carried out to determine the effect of $Z$ supplementation on intake, rumen environment and organic matter (OM) sites of digestion. Four Holstein steers, weighing $642 \mathrm{~kg}$ with rumen and duodenum proximal cannula were used. The experimental design was a cross over with 2 treatments and 2 periods. All animals were fed red clover (Trifolium pratense) and italian ryegrass (Lolium multiflorum) pasture (16\% CP, $36 \%$ NDF and $65 \%$ digestibility) and supplemented with $1 \mathrm{~kg}$ maize grain plus $2 \mathrm{~kg}$ wheat bran daily. Pasture was chopped and offered indoor, ad libitum three times per day. Treatments were TO : $0 \mathrm{~g} \mathrm{Z}$ and T1 : $500 \mathrm{~g} \mathrm{Z/animal/day.} \mathrm{VFA}$ concentration and molar proportions in rumen fluid were measured by gas chromatography. A Technicon autoanalyzer was used for $\mathrm{N}-\mathrm{NH}_{3}$ determination. $\mathrm{Na}$ and $\mathrm{K}$ in rumen fluid were estimated by atomic absorption. $\mathrm{Cr}_{2} \mathrm{O}_{3}$ and $\mathrm{Co}$ EDTA were used as solid and liquid markers (Uden, et al, 1980, J Sci Food Agric, 31, 625) for estimation of dilution rate and $O M$ and liquid flow to the duodenum (Armentano and Russell, 1985, J Dairy Sci, 68, 3067).

$Z$ supplementation increased rumen fluid $\mathrm{pH}$, $\mathrm{Na}$ concentration, $\mathrm{C}_{2}: \mathrm{C}_{3}$ ratio but decreased total VFA concentration, propionate and butyrate proportion and potassium concentration. Mean rumen $\mathrm{N}-\mathrm{NH}_{3}$ concentration was not different among treatments but it was observed that $\mathrm{N}-\mathrm{NH}_{3}$ was trapped during daytime and liberated at night in steers receiving $Z$. Molar proportion of acetic acid, dilution rate and liquid flow to the duodenum were not affected. The $Z$ tended to increase OM intake and OM total apparent digestibility. Treatment showed no difference in $\mathrm{OM}$ and liquid flow to the duodenum and OM apparently digested in the rumen.

In conclusion, in the present trial condition, $Z$ supplementation tended to increase OM intake, altered rumen environment, modified mineral balance, increased total OM digestibility and changed the sites of digestion.

\begin{tabular}{|c|c|c|c|}
\hline & TO & $\mathrm{T} 1$ & \\
\hline $\mathrm{pH}$ & 6.47 & 6.51 & $p<0.1$ \\
\hline $\mathrm{N}-\mathrm{NH}_{3}$ & 11.4 & 11.1 & ns \\
\hline VFA $(\mathrm{mmol} / \mathrm{l})$ & 103.1 & 84.8 & $P<0.01$ \\
\hline Acetic Ac (mol \%) & 56.3 & 56.6 & ns \\
\hline Propionic Ac (mol \%) & 25.1 & 23.7 & $P<0.05$ \\
\hline Butyric Ac (mol \%) & 15.6 & 16.2 & $P<0.1$ \\
\hline $\mathrm{C}_{2}: \mathrm{C}_{3}$ & 2.3 & 2.4 & $P<0.1$ \\
\hline $\mathrm{Na}(\mathrm{meq} / 100 \mathrm{ml})$ & 5.6 & 8.1 & $P<0.01$ \\
\hline $\mathrm{K}(\mathrm{meq} / 100 \mathrm{ml})$ & 5.7 & 3.4 & $P<0.01$ \\
\hline OM intake (g/kg BW) & 15.6 & 17.1 & $P<0.1$ \\
\hline Total OM Apparent Digestibility (\%) & 65.9 & 76.0 & $P<0.05$ \\
\hline OM apparent digestibility in rumen (\%) & 42.5 & 45.2 & ns \\
\hline OM flow to duodenum $(\mathrm{g} / \mathrm{kg} \mathrm{BW})$ & 8.9 & 9.3 & ns \\
\hline Liquid flow $(\mathrm{l} / \mathrm{h})$ & 6.5 & 5.6 & ns \\
\hline Dilution rate $(\% / h)$ & 12.4 & 10.7 & ns \\
\hline
\end{tabular}

